\title{
Aktivizujúce metódy a postupy vo vyučovaní obchodnej ruštiny študentov-nefilólogov
}

\author{
Activating methods and procedures in teaching business Russian \\ to non-philologists
}

\author{
Lenka Alieva
}

\begin{abstract}
Abstrakt: Príspevok sa venuje problematike metód a postupov vo vyučovaní obchodnej ruštiny, prostredníctvom ktorých sa zvyšuje efektivita v ovládaní odbornej slovnej zásoby. Aktivizujúce procesy nasmerované na aktívnu prácu študentov na hodinách ruského jazyka vedú k osvojovaniu si slovnej zásoby v predmetovej oblasti a štýlu obchodnej komunikácie.V príspevku prezentujeme varianty cvičení, prácu s textom, videocvičenia, audionahrávky, ktoré sú zamerané na osvojovanie správnych slovných spojení, ich používanie vo vetách a touto cestou na vyjadrovanie ucelených myšlienok. Uvedomujeme si pritom, že slovo, slovné spojenie nie je možné osvojit' si plnohodnotne mimo kontextu. Vo vyučovacom procese preto študenti pracujú s konkrétnymi komunikačnými situáciami, hraním rolí v obchodných situáciách. Prostredníctvom výskumu sa usilujeme o zistenie najefektívnejších spôsobov ako vzbudit’ záujem študentov o odborný ruský jazyk, udržat' ich pozornost' a produktívnu aktivitu počas vyučovacej jednotky a tým dosiahnut' pozitívne výsledky v podobe dobrého ovládania odborného cudzieho jazyka.
\end{abstract}

Klúčové slová: aktivizujúce procesy, vyučovanie ruského jazyka ako cudzieho, štýl obchodnej komunikácie, jazykové a predmetové kompetencie, produktívna aktivita

\begin{abstract}
This paper deals with the methodological and procedural issue of teaching business Russian aimed at increasing efficiency in acquisition of specific vocabulary. The activating processes are focused on activities of students at the lessons of the Russian language and they lead to the acquisition of both vocabulary in the specified field and the style of business communication. In this paper there are demonstrated different types of exercises, reading comprehension, video tasks, audios aimed at acquisition of appropriate word combinations, their application in sentences and at the end expressing complete ideas. We are aware of the fact that a word or a word combination can't be learned adequately without the context. Therefore during the lessons the students work with particular communication situations, role-playing in actual business case studies. In our research we try to identify the most effective methods how to arouse concern of students for the specific Russian language, moreover sustain their attention and productive activity during the whole teaching process in order to achieve positive results in the form of natural acquisition of a specific foreign language.
\end{abstract}

Key words: the activating processes, business Russian, the teaching proces, business communication, specific vocabulary, productive activity 


\section{Úvod}

V posledných desat'ročiach sa ruský jazyk čoraz častejšie využíva v medzinárodnom obchode. Tento fakt stimuluje študentov ekonomického zamerania počas vysokoškolského štúdia vyberat' si popri anglickom a nemeckom jazyku predmet ruský jazyk ako cudzí v ekonomickej oblasti pre jeho praktické využitie ako komunikačného prostriedku v ich dalšom profesijnom napredovaní. Rozvoj komunikačných schopností u študentov je možný na základe určitého minima gramatických, lexikálnych vedomostí a komunikačných zručností a ich následného správneho používania $\mathrm{v}$ praxi. Prístup $\mathrm{k}$ vyučovaciemu procesu ako maximálne kooperatívnemu tréningu $\mathrm{v}$ rámci učebného materiálu sa $\mathrm{v}$ súčasnej metodickej praxi javí populárnym trendom. Súvisí to so súčasnými požiadavkami týkajúcimi sa vzdelania a požiadaviek, ktoré sa kladú na ekonomicky vzdelaného absolventa vysokej školy. Ovládanie ruského jazyka v profesijnej oblasti ekonomického profilu zabezpečí študentom pripravenost' na reálne komunikačné situácie. Prvoradou úlohou vo vyučovaní obchodnej ruštiny je preto formovanie odborných a komunikačných kompetencií študentov. Za hlavný ciel vyučovania považujeme dosiahnutie plynulého ovládania ruského jazyka ako prostriedku obchodnej komunikácie. V súvislosti s definovaním daného pojmu I. A. Sternin, považuje obchodnú komunikáciu za jednu z poddisciplín vednej disciplíny tzv. verbálnej interakcie (речевого воздействия). Podla autora predmetom verbálnej interakcie je efektívna komunikácia $(2015$, s. 3). Obchodnú komunikáciu autor definuje ako „vedu o efektívnej komunikácii na dosiahnutie človekom predmetového ciela v rámci spoločenskej komunikácie“ (2015, s. 4). Ako uvádza O. E. Solanik, „v súlade s výslednými ciel'mi vyučovania sa vyberá jazykový materiál, okruh komunikačných situácií, prevažujúce rečové formy a druhy komunikácie, ku ktorým musí byt' študent pripravený pri hodnotení" (2013, s. 135). Cielom nášho príspevku je predstavit’ na konkrétnych príkladoch aktivizujúcich metód vo vyučovacom procese špecifiká disciplíny ruský jazyk ako cudzí v ekonomickej oblasti a optimálne spôsoby formovania lingvistickej a komunikatívnej kompetencie u študentov danej špecializácie. L'. Bagalová vo svojom príspevku o globálnom rozvojovom vzdelávaní, ktorého podstatou je spôsob učenia, ktorý dáva veciam zmysel, uvádza podla J. Čápa a J. Mareša práve aktívnost' učenia sa ako jednu zo všeobecne-didaktických požiadaviek na zmysluplné učenie sa (2015, s. 2).

\section{Aktivizujúce metódy a postupy vo vyučovaní obchodnej ruštiny}

V rámci vyučovania ruského jazyka ako cudzieho formujeme u študentov lexikálnu a následne sa odvíjajúcu komunikatívnu kompetenciu. Berieme pri tom do úvahy ich ekonomické zameranie. Našim hlavným cielom pri vyučovaní ruského jazyka je aktivizácia zručností ústnej komunikácie na základe preberaného učiva, aby po niekol'kých semestroch študenti dokázali plynule používat' ruský jazyk v praxi. Pri definovaní pojmu aktivizujúca metóda sa opierame o tvrdenie V. V. Mačnevovej, 
ktorá za aktivizáciu považuje „neustále prebiehajúci proces podnecovania k aktívnemu, cielavedomému učeniu, prekonávanie pasívnej a stereotypnej činnosti, pokles v myšlienkovej činnosti“ (2000, s. 48). Podstatou aktívnych resp. aktivizujúcich vyučovacích metód je rovnocenná účast' vo vyučovacom procese učitela a študenta nasmerovaná na dosiahnutie vzdelávacích ciel'ov. Dominuje v nich aktívnost' študentov pri riešení úloh, v ktorých spolupracujú pri spracovaní praktických zadaní pri osvojovaní si učebného materiálu. Charakteristickou črtou aktívnych vyučovacích metód je myšlienková aktivizácia v priebehu istej časti alebo aj celej vyučovacej jednotky, samostatnost' v rozhodovaní, motivácia, rôznorodost' aktivít. A. Petríková uvádza, že „záujem na hodine vzniká vtedy, ak je študent aktívny, je definovaný problém riešenia, práca je rôznorodá, mení sa rytmus práce a typy cvičení a študent vidí dosahovanie ciela" (2013, s. 53). Súhlasíme s tvrdením V. V. Mačnevovej, že jedným z najdôležitejších princípov intenzifikácie vo vyučovacom procese je práve motivácia, ktorú R. S. Nemov definuje ako „cielavedomé konanie, organizovanost' a stabilitu celkovej činnosti na dosiahnutie určitého ciela“" (Mačnevová, 2000, s. 47). Jedným z dôvodov práce na vyučovacej jednotke prostredníctvom aktivizujúcich metód je krátka časová dotácia. G. A. Kitajgorodská podstatu intenzívneho vyučovania cudzieho jazyka vidí v obsahu kurzu, do ktorého patrí „osvojenie si súboru zručností, dostatočných nevyhnutných na efektívne uskutočnenie činnosti v konkrétnej sfére, a taktiež osvojenie si jazykového materiálu, ktorý zabezpečuje formovanie a používanie týchto zručností“ (Mačnevová, 2000, s. 46).

Metódy sú prispôsobované tréningu štandardných situácií ústnej obchodnej komunikácie (oficiálne zoznamovanie, predstavovanie firmy, obchodné rokovania, prezentácie v powerpointe), bežnej obchodnej komunikácii (telefonické rozhovory) a obchodnej korešpondencii (reklamný list firmy s návrhom na spoluprácu). T. D. Blum a T. I. Riazanceva hovoria v tejto súvislosti o ,jazyku obchodnej komunikácie" v širšom význame. Vychádzajú z ruských teoretických metodík vyučovania ruského jazyka ako cudzieho A. N. Ščukina a E. G. Azimova. Do oblasti obchodnej komunikácie patria nielen porady, rokovania vo firme alebo obchodná korešpondencia ale aj všetky ostatné situácie, s ktorými sa stretávame v rámci služobných ciest do ruskohovoriacich krajín ako aj pri host'ovaní ruskohovoriacich delegácií $(2017$, s. 146). Kto ovláda príslušnú slovnú zásobu ekonomickej oblasti, dokáže pri riešení úloh zameraných na komunikáciu reagovat’ na konkrétne situačné kontexty. Opierame sa o tvrdenie L. P. Pavlovej, že „celý proces výučby cudzieho jazyka na odborné ciele musí byt' maximálne prispôsobený reálnej profesionálnej činnosti daného odborníka" (2013, s. 3). V rámci výučby ruského jazyka v obchodnej sfére vd’aka situačno-komunikatívnym rečovým aktivitám si študenti osvojujú gramatické javy vyskytujúce sa v ustálených slovných spojeniach. Vo vyučovacom procese sa sústred'ujeme na výber prostriedkov komunikácie, ktoré zodpovedajú cielu vyučovania a prostrediu, v ktorom komunikačný proces prebieha. Komunikačný proces sa vo vyučovacom procese uskutočňuje prostredníctvom imitatív- 
neho modelu, podstatou ktorého je napodobovanie situácií predmetovej oblasti. Aktivizujúca činnost' na hodinách ruského jazyka v obchodnej sfére je najproduktívnejšia za podmienok prelínania učebnej situácie s reálnou komunikáciou, o ktorú sa $\mathrm{v}$ našich podmienkach usilujeme prostredníctvom trénovania praktických zručností v cudzom jazyku (náčuv s porozumením, písomný prejav) a formovania komunikačných zručností (verbálna komunikácia). Ako uvádza O. I. Košeleva, „charakteristickými vlastnostáami aktívnych metód učenia sa cudzieho jazyka sú:

1. cielavedomá aktivizácia myslenia (študent musí byt’ aktívny nezávisle na jeho prianí);

2. dlhší čas zapojenia študentov do vyučovacieho procesu;

3. samostatné tvorivé spracovanie riešení, zvýšená motivácia a emocionalita študentov;

4. interaktívny charakter, t. z. neustála spolupráca subjektov vyučovacieho procesu" (2018, s. 111).

V súčasnosti považujeme za aktivizujúce formy vo vyučovaní ruského jazyka v ekonomickej oblasti nasledovné:

- skupinové vyučovanie,

- inscenačné metódy/hranie rolí,

- situačné úlohy,

- práca s videonahrávkami a mentálnymi mapami,

- lexikálne a gramatické hry s jazykom,

- prezentovanie,

vd’aka ktorým sa usilujeme zatraktívnit' tento jazyk a zefektívnit' osvojovanie si jeho komunikačných úloh $\mathrm{v}$ obchodnej sfére tak v ústnej ako aj písomnej forme. Podstatou vymenovaných typov aktivizujúcich metód je hra. Za hru považujeme formu upevňovania a aktivizácie učebného materiálu v príznačných situáciách pre túto oblast' komunikácie. Využívaním rôznorodých modelov praktických cvičení sa usilujeme o čo najautentickejšie priblíženie k reálnym situáciám. Úlohou učitela je nachádzat' formy práce $\mathrm{s}$ jazykom, ktoré vedú študentov $\mathrm{k}$ samostatnej a aktívnej činnosti v priebehu vyučovacej hodiny. S jazykovým materiálom predmetovej oblasti pracujeme podla princípu postupnosti smerom od učenia sa tematickej slovnej zásoby k zložitejšiemu formovaniu monologickej alebo dialogickej reči $\mathrm{s}$ využitím už osvojených slovných spojení preberanej témy. Ako uvádza V. A. Falina, „kultúra profesionálnej komunikácie obsahuje: zvládnutie terminológie danej oblasti, schopnost' produkovat' prejav na profesionálnu tému, schopnost' organizovat' dialogickú reč a viest' ju, schopnost' komunikovat' s obchodnými partnermi v odbornej rovine" $(2017$, s. 7). 
Systém vyučovania odborného ruského jazyka rozdel’ujeme na dve etapy:

1. osvojovanie novej slovnej zásoby predmetovej oblasti (predkomunikatívne zadania),

2. rozširovanie vedomostí z lexikálnej a komunikatívnej roviny (komunikatívne úlohy).

V prvej fáze osvojovania prípadne upevňovania novej slovnej zásoby predmetovej oblasti sa využívajú na hodinách predkomunikatívne cvičenia: lexikálne, gramatické a mentálne mapy.

- V hre pod názvom „Obal’ ma“ jeden študent vyslovuje slovo z preberanej témy. Ostatní študenti k nemu prirad'ujú zodpovedajúce podstatné meno, prídavné meno, sloveso. So slovom "услуга" takýmto spôsobom vznikajú slovné spojenia „предоставлять/предлагать/оказывать услуги, платная услуга, юридические услуги, услуги парикмахера" atd'. V tejto hre sa študenti usilujú o čo najrýchlejšie vytvorenie slovného spojenia. Tento spôsob práce napomáha rýchlejšiemu osvojeniu si prípadne zautomatizovaniu už osvojenej slovnej zásoby. V niektorých cvičeniach dochádza k prelínaniu lexikálnej a gramatickej hry.

- Ako napríklad v hre „Druhá polovica“, kde študenti k slovu prirad'ujú slovo, slovné spojenie správne z lexikálneho aj gramatického hladiska. Študenti sú rozdelení na dve a viac skupín. V rámci témy povolania sútažia kto $\mathrm{k}$ slovu „менеджер, директор, глава“ vytvorí viac slovných spojení.

- Hra „Synonymické rady“ sa využíva najčastejšie pri téme firma. V tejto hre na slovo „фирма“ študenti nadväzujú d’alšími slovami „компания, предприятие, концерн, кооперация, завод, общество, объединение, фонд, бюро."

- "Nájdi nedostatok" je hra na hladanie chýb v slovných spojeniach. Pri identifikácii chybného slovného spojenia, nesprávne použitej predložky sa študenti v budúcnosti vyvarujú týchto chýb.

- Dôležitou častou práce so slovnou zásobou a následným vytváraním logicky ucelených myšlienkových výpovedí sú mentálne mapy, ktoré majú široké uplatnenie $\mathrm{v}$ rôznych variantoch. Pod pojmom mentálna mapa rozumieme grafické znázornenie slovných asociácií ku konkrétnej téme. Naše skúsenosti a systém práce na hodinách mentálne mapy zarad'ujú nielen medzi predkomunikatívne lexikálno-gramatické cvičenia ale aj komunikatívne. Mentálne mapy spracovávajú študenti v skupinách. Pracujú na základe asociácií ku konkrétnym slovám „заниматься, являться, работать“, v rámci témy činnost' firmy a gramatického javu konštrukcií s inštrumentálom. Následne si tieto mentálne mapy vymenia v skupinách a pracujú na produkovaní komunikačnej situácie $s$ použitím uvedených slov v mentálnej mape. Bud' ide o dialogickú reč alebo monologickú, do ktorej sa zapoja všetci študenti zo skupiny, každý s istou ústnou výpovedou. 
Na konci zadania vzniká ucelený obraz o ich téme. $\mathrm{V}$ rámci témy predstavenie firmy si študenti v skupine navrhnú mentálnu mapu na to, aby z nej následne mohli vytvorit’ projekt svojej vlastnej firmy od názvu, činnosti až po filiálky, personál a kontaktné údaje. Mentálne mapy vznikajú tematické, sémantické, gramatické. Dominantnou črtou mentálnych máp je ich názornost'.

Vo fáze rozširovania lexikálnej a komunikatívnej roviny jednými z najefektívnejších komunikačných imitatívnych aktivizujúcich metód, ktoré v súčasnosti patria medzi populárne vo vyučovaní cudzích jazykov, sú inscenačné metódy, hranie rolí, resp. situačné úlohy. Inscenačné metódy majú svoje opodstatnenie pri témach: Zoznamovanie, Obchodné stretnutia, Obchodné rokovania, Predstavovanie firmy, Pracovný pohovor, Telefonovanie ale aj Prezentácia firmy. Podstatou týchto metód je napodobňovanie reálnej komunikácie. „Metóda hrania rolí pozitívne vplýva na formovanie poznávacích záujmov študentov, prispieva k vedomému osvojovaniu si cudzieho jazyka" (Sbitnev, 2012, s. 132). Považujeme ju za aktivizujúci a motivačný spôsob učenia sa praktickému ovládaniu cudzieho jazyka. Štruktúrne metóda hrania rolí pozostáva z troch častí. Každému študentovi je pridelená konkrétna rola, svoj ústny výstup organizujú podla úloh pridelenej situácie, v ktorej budú viest' komunikáciu. Výstupnou častou tejto metódy je samotný proces hrania rolí v určenej komunikačnej situácii. Všetci zúčastnení sú po celú dobu trvania hranej situácie aktívni, pretože pracujú s maximálnou možnou mierou vedomého osvojovania si cudzieho jazyka. V tomto type zadaní sa práca študentov odvíja od vopred pripravenej štruktúry na nižšom stupni ovládania cudzieho jazyka alebo si študenti podla témy pripravujú realizáciu situácie sami.

Vychádzajúc z praktických skúseností za tvorivú aktivizujúcu úlohu považujeme dialogickú reč. $\mathrm{V}$ prvotných frázach nedokončeného dialógu je len predstavená komunikačná situácia, ktorá sa následne bude rozvíjat' vd’aka tvorivého prístupu študentov. Ide predovšetkým o telefonické rozhovory v rôznych variantoch (nesprávne zvolené číslo, dovolali sme sa priamo pracovníkovi, ktorého potrebujeme, radi by sme sa spojili s pracovníkom, s ktorým riešime spoločný projekt, pozvanie na výstavu/konferenciu, návrh spolupráce atd') Študenti majú v zadaní konkretizovaný scenár rozhovoru. $\mathrm{V}$ tomto type práce s cudzím jazykom dbáme na osvojovanie formálnych ustálených fráz, slovných spojení telefonických rozhovorov.

Pri práci so zodpovedajúcou slovnou zásobou v reálnom kontexte má nezastupitel'né miesto video. Videá - prezentácie firiem sú len podkladom pre následnú prípravu študentov na ucelené prezentovanie. Prostredníctvom videí študenti majú tesný kontakt $s$ fonetickou rovinou ruského jazyka a reálnym tempom reči. Dôležitú úlohu zohráva náčuv s porozumením. Študenti pracujú v skupinách, ktoré budú následne spracovávat' vypočutú informáciu o firmách v podobe hrania rolí v prezentácií. Každý študent prezentuje istú čast' informácií o firme. Informáciu si spracovávajú tak, aby mohli vytvorit’ svoju vlastnú ucelenú prezentáciu firmy. 
Okrem vypočutých údajov zarad’ujú už do svojich ústnych výpovedí aj prezentačné frázy.

\section{Záver}

V našom príspevku sa usilujeme poukázat' na opodstatnenost' využívania aktivizujúcich metód na hodinách ruského jazyka pri osvojovaní si celej škály aktívnej lexikálnej, gramatickej a štylistickej roviny príznačnej pre obchodnú ruštinu počas relatívne krátkej časovej dotácie. Našim cielom v kvantitatívnej analýze vyučovacej hodiny bolo zistit', či študentom vyhovuje aktívny priebeh hodiny, do ktorého sú zapojení v priebehu celej hodiny alebo istej jej časti. Údaje sme získavali prostredníctvom dotazníka na zistenie miery efektivity v rámci aktivizujúcich metód pri vyučovaní ruského jazyka v ekonomickej oblasti pozostával z ôsmich otázok. Pracovali sme s výskumnou vzorkou 28 študentov. Jednotlivé otázky boli formulované tak, aby na nich študenti odpovedali tvrdením áno/nie, vyjadrili svoj názor a vybrali si z produktivít práce využívaných na hodinách ruského jazyka podla vlastnej preferencie. Aktívna práca na hodinách vyhovuje 23 študentom (82\%). Piati študenti (5\%) sa prikláňali ku tradičnej forme vyučovania, pod ktorou považujú frontálny spôsobom vyučovania. V otázke, či aktívnou formou práce na hodinách si osvojujú slovnú zásobu, komunikačné modely už počas vyučovacej hodiny, odpovedalo kladne 18 (64\%) študentov, 10 (36\%) študentov sa preberaný lexikálny materiál potrebujú zopakovat’ doma. Študenti sa v dotazníku vyjadrovali podla svojej vlastnej produktivity k najefektívnejším formám vyučovania. Case study resp. skupinovú prácu uprednostňuje 15 (53\%), hranie rolí 17 (61\%) študentov, 18 (64 \%) študentov situačné úlohy uvádza ako jednu z možností riešenia komunikačných situácií zo svojho odboru a zároveň v cudzom jazyku, práca s videonahrávkami a mentálnymi mapami vyhovuje 21 (75\%) študentov, lexikálne a gramatické hry s jazykom však vyhovuje 13 (46\%) študentom, čo je menšia polovica.

Vyplýva z toho, že študenti majú radšej prácu kolektívnu, do ktorej môžu vkladat' svoje poznatky, skúsenosti. Prezentovanie, ktoré je aj hodnotené na konci semestra ako semestrálne zadanie uviedlo 18 (64\%) študentov za efektívnu prácu s jazykom. V súvislosti s prezentovaním a skupinovou prácou pocítilo najviac študentov svoj osobný pokrok v ovládaní ruského jazyka ekonomického zamerania, a síce tvorenie vlastných prezentácií a samotné vystupovanie pred publikom. Najväčším prínosom, podla názoru študentov, je rozvoj samostatného, analytického, tvorivého myslenia v cudzom jazyku. Môžeme tvrdit', že študenti nie sú ohraničovaní presným scenárom, každá úloha sa na vyučovacej hodine vyvíja. Učitel' študentom pomáha s váhaním pri výbere správnych lexikálnych jednotiek a gramatických javov. Do obsahu, ktorý tvoria študenti, sa usiluje nezasahovat'. Prácu študentov zhodnotí po ich výkone, kde vyzdvihne silné stránky upozorní na slabé stránky. Po každej aktivite dostávajú študenti od učitela spätnú väzbu. 
Rozvoj komunikatívnych zručností prostredníctvom rôznorodých aktivít v skupinách predovšetkým imitovaním reálnych situácií vyhovuje 82 \% študentov prvého ročníka. Takúto formu organizácie vyučovacej hodiny považujú za atraktívnu, efektívnu a modernú. Študenti oceňujú túto formu osvojovania si komunikačných zručnosti v ruskom jazyku pre prax. Najdôležitejším faktorom rozvoja komunikatívnych zručností je aktívne zapojenie každého študenta do riešenia úloh. $\mathrm{K}$ tréningu plynulého ovládaní ruského jazyka študentov vedie vonkajšia motivácia zo strany učitela, ktorý vd’aka aktivizujúcim metódam dokáže udržiavat' pozornost' počas celej doby trvania vyučovacej jednotky.

Z nášho výskumu môžete tvrdit', že podstatnou črtou aktivizujúcich metód vo vyučovaní ruského jazyka v ekonomickej oblasti je podnecovanie študentov k spoločnej resp. kolektívnej práci, vyjadreniu svojho postoja, názoru, rešpektovaniu názoru iných a snahe nájst' jednotné riešenie. Výber aktivizujúcich metód na hodinách ruského jazyka v ekonomickej oblasti sa opiera o požiadavky súčasného vzdelávania pre prax. Za najefektívnejšiu aktivizujúcu metódu môžeme považovat' tzv. hru $\mathrm{s}$ jazykom v zadaniach vyplývajúcich $\mathrm{z}$ ich špecializácie. Osvojovanie slovnej zásoby predmetovej oblasti, gramatických javov ustálených slovných spojení, štýlu obchodných rokovaní, komunikačných situácií sa najaktívnejšie uskutočňuje kolektívnou formou. U väčšiny študentov sme pozorovali prekonávanie jazykovej bariéry. Atmosféra v týchto skupinách je uvol'nenejšia ako pri frontálnom spôsobe vyučovania. Aktívnost' vyučovacieho procesu hraním rolí, rôznymi úlohami na osvojovanie si príslušnej lexikálnej a gramatickej roviny sa uskutočňuje vdaka učeniu sa v činnosti. Študenti tento typ cvičení na hodinách považujú za maximálne produktívnu prácu vd’aka používaniu slovnej zásoby ekonomickej oblasti v rôznych kontextoch. Pri tomto type cvičení je základnou úlohou učitel'a pozorovanie a fixovanie chýb a ich následná analýza s ponukou možností ich riešenia. Tréningové situácie hrané v roliach môžu využívat' v reálnych komunikačných situáciách v obchodnej sfére. Po dvoch až štyroch semestroch systematickej prípravy sú študenti schopní samostatne vyprodukovat' dialogickú a monologickú reč v situáciách najpríznačnejších pre obchodnú komunikáciu. Upevňovanie už osvojených zručností aktívnou formou je bezprostredné, zrýchl'uje a zjednodušuje upevňovanie jazykových javov v pamäti. Ako jeden zo špecifických znakov aktivizujúcich metód $64 \%$ študentov uviedlo moment prekvapenia pri zadávaní úlohy učitelom, od ktorého sa odvíja spoločná práca v skupine a moment očakávania z výsledku ich zadania. Obidva momenty sa odvíjajú od atmosféry, ktorá sa v úlohe očakáva a zmeny ich identity. Pomocou aktivizujúcich metód, ktoré uvádzame, študenti nadobúdajú zručnosti obchodnej komunikácie $s$ ovela širšou slovnou zásobou a zložitejším tvorením fráz ústnej komunikácie. Popularita využívania aktivizujúcich metód vyplýva z produktívneho osvojovania nových jazykových a komunikačných modelov vd’aka zvyšovaniu motivácie a udržiavaniu pozornosti študentov. Vyučovací proces organizovaný prostredníctvom aktivizujúcich metód vedie $\mathrm{k}$ úspešnému budovaniu komunikačnej kompetencie študentov ekonomického zamerania. 


\section{Literatúra}

Bagalová, L'. (2015). Aktivizujúce metódy výučby v globálnom rozvojovom vzdelávaní. [online]. Dostupné z: http://www.statpedu.sk/files/articles/dokumenty/ucebnice-metodiky-publikacie/globalne_ vzdelavanie_metody_vystup-phu_20.pdf

Блюм, Т. Д., РязАнцЕВА, Т. И. (2017). Возможно ли обучение деловому общению с нуля? Вестник. № 31. Современный русский язык: Функционирование и проблемы преподавания. Будапешт 2017. 334 c. [online]. Dostupné z: http://pbn.nauka.gov.pl

ЕвтушЕнко, С. Я. (2016). Особенности обучения деловому общению иностранных студентов в аспекте русского языка как иностранного. [online]. Dostupné z: https://cyberleninka.ru/article/ n/osobennosti-obucheniya-delovomu-obscheniyu-inostrannyh-studentov-v-aspekte-russkogoyazyka-kak-inostrannogo/viewer

КошЕЛЕВА, О. И. (2018). Возможности применения активных методов обучения в профессиональных образовательных организациях. [online]. Dostupné z: http://elar.urfu.ru/ bitstream/10995/59271/1/nop-2-2018-23.pdf

МАчневА, В. В. (2000). К вопросу об интенсификации обучения иностранному языку в условиях университета. [online]. Dostupné z: https://cyberleninka.ru/article/v/

k-voprosu-ob-intensifikatsii -obucheniya-inostrannomu-yazyku-v-usloviyah-universiteta

ПАВловА, Л. П. (2013). Формирование лексической компетентности у студентов экономического вуза в процессе профессионального направленного обучения иностранному языку. [online]. Dostupné z: https://cyberleninka.ru/article/n/formirovanie-leksicheskoy-kompetentnosti -u-studentov-ekonomicheskogo-vuza-v-protsesse-professionalnogo-napravlennogo-obucheniya/ viewer

ПЕТРИковА А., КУПРИнА Т., ГАЛЛо, Я. (2013). Введение в дидактику русского языка и межкультурную коммуникацию. Прешов: ФФ Прешовского университета.

СБитнев, К. В. Ролевая игра в обучении иностранного языку студентов I-го курса неязыкового вуза. [online]. Dostupné z: https://cyberleninka.ru/article/n/rolevaya-igra-v-obuchenii-inostrannomu -yazyku-studentov-i-go-kursa-neyazykovogo-vuza/viewer

Соляник, О. Е. (2013): Иностранные бакалавры в Российском Техническом вузе: Проблемы и специфика обучения русскому языку. [online]. Dostupné z: https://cyberleninka.ru/article/n/ inostrannye-bakalavry-v-rossiyskom-tehnicheskom-vuze-problemy-i-spetsifika-obucheniyarusskomu-yazyku/viewer

СтЕРнин, И. А. (2012). Основы речевого воздействия/Учебное издание. Москва-Берлин. Директ-Медиа. [online]. Dostupné z: http://sterninia.ru/files/757/4Izbrannye_nauchnye_ publikacii/Rechevoe_ vozdejstvie/Osnovi_recevogo_vozdeistviya2013.pdf

ФАлинА, В. А. (2017). Деловой русский язык в сфере профессиональной коммуникации: Учеб. пособие. Иваново. ФГБОУ ВО «Ивановский государственный энергетический университет имени В.И. Ленина». [online]. Dostupné z: http://ispu.ru/files/FalinaVA_Delovoy_russkiy_yazyk._Uchebnik.pdf

ЧЕсноковА, М. П. Методика преподавания русского языка как иностранного: учеб. пособие. 2 изд., перераб. М. МАДИ, [online]. Dostupné z: http://lib.madi.ru/fel/fel1/fel15E327.pdf

\section{Autorka}

Mgr. Lenka Alieva, PhD., Katedra jazykov Technickej univerzity v Košiciach, e-mail: lenka.alieva@tuke.sk Lenka Alieva pracuje na Katedre jazykov Technickej univerzity v Košiciach ako odborný asistent. Vyučuje ruský jazyk v ekonomickej oblasti a odborný ruský jazyk v cestovnom ruchu. Vo svojej vedeckej a metodickej práci sa venuje otázkam inovatívnych metód vo vyučovaní ruského jazyka ako cudzieho v neruskom prostredí. 